\title{
Leaf Blade Quantitative Anatomy of Sugarcane Cultivars and Clones $^{1}$
}

\author{
Anatomia Quantitativa da Lâmina Foliar de Genótipos de Cana-de-Açúcar \\ FERREIRA, E.A. ${ }^{2}$, VENTRELLA, M.C. ${ }^{3}$, SANTOS, J.B. ${ }^{4}$, BARBOSA, M.H.P. ${ }^{5}$, SILVA, A.A. ${ }^{5}$, \\ PROCÓPIO, S.O. ${ }^{6}$ and SILVA, E.A.M. ${ }^{7}$
}

\begin{abstract}
The objective of this study was to make a quantitative assess of the anatomic characteristics of leaf blade of the sugarcane cultivars RB855113, SP80-1842, SP80-1816, RB867515 and clone RB957689 presenting different sensitivity to the mixture of sodium trifloxysulfuron + ametryn herbicides. Compared to the other cultivars assessed, RB855113 cultivar, considered more sensitive to the herbicide mixture, presented relevant differences such as greater proportion of bulliform cells, greater tissue proportion in the transverse section of the leaf blade, greater stomata and trichome density on both surfaces, thinner epidermis on the adaxial surface and length of stomata on both surfaces. The external paraclinal wall of the bulliform cells was thinner than in the common epidermis cells in all the genotypes on the adaxial and abaxial surfaces. Multivariate analysis of the data on the variables considered most relevant to explain the herbicide penetration singled out the sensitive RB855113 from the other materials. Such characteristics can explain the greater penetration, and consequently, greater sensitivity of this cultivar to the sodium trifloxysulfuron + ametryn mixture.
\end{abstract}

Keywords: leaf anatomy, herbicide, Saccharum sp.

RESUMO - Objetivou-se neste trabalho avaliar, quantitativamente, as características anatômicas da lâmina foliar dos cultivares de cana-de-açúcar RB855113, SP80-1842, SP80-1816e RB867515 e do clone RB957689 com diferentes sensibilidades à mistura dos herbicidas trifloxysulfuron-sodium + ametryn. O cultivar RB855113, considerado mais sensivel à mistura de herbicidas, mostrou diferenças relevantes em relação aos demais cultivares avaliados, como: maior proporção de células buliformes, tecido encontrado em maior proporção na seção transversal da lâmina foliar desse cultivar, maior densidade de estômatos e de tricomas em ambas as faces, epiderme menos espessa na face adaxial e estômatos com maior comprimento de ostiolos nas duas faces. Todos os genótipos apresentaram a parede periclinal externa das células buliformes mais delgada do que nas células epidérmicas comuns, nas faces adaxial e abaxial. A análise multivariada dos dados relacionados às variáveis consideradas mais relevantes para explicara penetração de herbicidas distinguiu o cultivar sensivel RB855113 dos demais materiais. Essas características podem explicar a maior penetração e, conseqüentemente, a maior sensibilidade desse cultivar à mistura trifloxysulfuron-sodium + ametryn.

Palavras-chave: anatomia foliar, herbicida, Saccharum sp.

Recebido para publicação em 12.7.2006 e na forma revisada em 27.2.2007.

Eng.-Agrônomo, Doutorando em Fitotecnia da Universidade Federal de Viçosa - DFT/UFV, 36570-000 Viçosa-MG, <evanderalves@yahoo.com.br>; ${ }^{3}$ D.Sc., Professora do Departamento de Biologia Vegetal - DBV/UFV; ${ }^{4}$ D.Sc., Professor da Universidade do Vale do Rio Doce - UNIVALE, Governador Valadares-MG; ${ }^{5}$ Professor Associado - DFT/UFV. ${ }^{6}$ D.Sc., Professor da Faculdade de Agronomia da Universidade de Rio Verde - FESURV. ${ }^{7}$ Ph.D., Professor associado do Departamento de Biologia Vegetal - DBV/UFV 


\section{INTRODUCTION}

Sugar cane cultivars and clones have different sensitivity to herbicides which can cause crop damage, with significant reduction in sugar cane plantation yield (Procópio et al., 2003).

Knowledge of the mechanisms through which herbicides penetrate the plant tissues is fundamental for the correct use and efficiency of the product. Herbicides can penetrate the plant through the aerial structures (leaves, stems, flowers and fruits) and subterranean structures (roots, rhizomes, tubers, etc.) or, even through seeds during germination and emergence, through the radicle and epicotyl. However, the leaves are the main organs involved in the penetration of herbicides applied during the post emergence period (Silva et al., 2003).

The quantity of herbicide intercepted and retained in the leaves is mainly influenced by their morphology. However, the anatomical and micro morphological characteristics of the plant determine how easily these products will be absorbed (Hess \& Falk, 1990).

Van Dillewijn (1952) reported the work of others noting that the epidermis of sugarcane leaves presents formations such as bulliform cells, stomata, silica cells and trichomes. Artschawager (1925) identified three zones in the upper epidermis: 1) a central zone consisting of long cells alternated with groups of short cells, presenting trichomes and silica cells; 2) a stomata zone; and 3), a margin zone consisting of long cells alternated with short cells, also presenting trichomes and silica cells. Inexplicably, Artschwager diagrammed and discussed the role of bulliform cells in the upper epidermis but failed to list these as a fourth zone. He did, however, highlight the importance of the epidermis of the abaxial (lower) leaf surface in identifying cultivated sugarcane varieties, where silica cell and stomata distribution were diagnosed.

Plant leaves present various levels of trichomes and gland development. Abutilon theophrasti, for example, has simple and complex trichomes, while Chenopodium album has a high density of glandular trichomes in the adaxial epidermis that can hide the epidermis cells completely (Hess \& Falk, 1990). Trichomes, especially the branched ones, present on the leaf surface can intercept sprayed drops, preventing them from reaching the epidermis. Even when these trichomes are simple and appear in low density, the drops adhere to them. The absorption efficiency of herbicides by the trichomes and their translocation to the epidermis cells are partially understood (Hess \& Falk, 1990). However, according to Hull (1970), some absorption of chemical products may occur via the trichomes. Commelina benghalensis, more sensitive to glyphosate than Commelina diffusa, presented a greater trichome density than the more tolerant species (Santos et al., 2001). Nevertheless, few authors state that the trichomes are a pathway for herbicide entry in the leaves. Generally, a negative relationship seems to exist between herbicide adherence to the trichomes and the efficacy of these products (Hess \& Falk, 1990).

According to (Hess \& Falk, 1990), most weeds present stomata on the adaxial and abaxial surfaces (amphistomatic). Procópio et al. (2003) analyzed 20 weed species and observed that 19 were amphistomatic and only one was hypostomatic. Meyer et al. (1973) counted the number of stomata in 39 species, and observed that 16 were amphistomatic and the remaining 23 were hypostomatic. These authors also stated that in the amphistomatic, species, the number of stomata on the adaxial surface was, in most cases, lower than that on the abaxial surface.

The herbicide liquid drop, when sprayed on the leaf surface, can volatilize or be washed away by rain; it can also remain on the surface as a viscous liquid or in the form of crystal; it can penetrate, but remain absorbed in the lipophylic components of the cuticle; it can penetrate the cuticle and the cell wall and thus translocate before reaching the symplast. When the product penetrates the cuticle, the cell wall and reaches the cell interior (through the plasmalema), symplastic translocation occurs (Hess, 1995).

Barriers to herbicide penetration, such as high stomata density in Nicandra physaloides, thick epicuticle wax layer in Solanum viarum, Solanum americanum and 
Raphanus raphanistrum were also reported by Ferreira et al. (2003), in quantitative anatomy studies.

The cuticle covers the external paraclinal wall of the epidermis cells forming a covering consisting mainly of lipid substances. The cuticle is the main herbicide absorption pathway, so that understanding it is fundamental in studies on the absorption of these compounds (Procópio et al., 2003). This covering over the primary celullose wall, from the inside to the outside, consists of secondary cuticle or cutinized wall (cuticle plus wall), primary cuticle or cuticle itself, where embedded wax is found and, on the cuticle covering the most external part, the epicuticle wax (Herédia et al., 1998).

The objective of this study was to quantitatively assess the leaf blade anatomic characteristics of the sugar cane cultivars RB855113, SP80-1842, SP80-1816, RB867515 and clone RB957689 presenting different sensitivities to herbicides.

\section{MATERIAL AND METHODS}

The experiment was carried out in the Plant Growth Unit (UCP) of the Department of Plant Biology at the Federal University of Viçosa, in a protected environment. Pots containing six liters of Red-Yellow Argisol substrate were used. Two stools were planted and maintained with one shoot each. Pots were fertilized as recommended for sugar cane cropping (CFSEMG, 1999). A randomized block experimental design was used with five replications.

The sugar cane genotypes used in this experiment had been pre-selected in a previous study which analyzed the sensitivity of 15 sugar cane genotypes to the sodium trifloxysulfuron + ametryn herbicide mixture. The following were selected from these cultivars and clones for anatomical studies: RB855113 (sensitive to the herbicide mixture), SP801842, SP80-1816, (medium sensitivity to the mixture) and RB867515 (tolerant to the mixture) (Ferreira, 2005).

The youngest or uppermost leaf with a visible ligule was collected from five plants of each genotype. Samples were removed from the mid region of the leaf blade, fixed in FAA50, stored in 70\% ethanol (Johansen, 1940) and transported to the Plant Anatomy Laboratory of the Plant Biology Department at the Federal University of Viçosa.

Portions of $1 \mathrm{~cm}^{2}$ fixed blade segment were dehydrated in an ethylic series and blocked in historesin, according to manufacturer's recommendations (His toresin-Leica), cut transversely in a rotating microtome with automatic advance, with $8 \mu \mathrm{m}$ thick steel blades. The material was stained with toluidin blue $\mathrm{pH} 4$ (O`Brien et al., 1965) and mounted in synthetic resin (Permount). The epidermis impression with instant glue method was used to observe the leaf surface on both the blade surfaces (Rodella et al., 1993).

To visualize the cuticle, cross sections were made, stained with scarlet red Sudan, and mounted between slides and cover slips with glycerinated gelatin.

Digitalized images of the sections were obtained with a light microscope attached to a digital camera and connected to a microcomputer. The image Pro plus computer program was used to obtain data on the area and linear means. A light chamber attached to the microscope was used to count.

The following anatomic characteristics were determined for the transverse section of the leaf blade, using a 10x lens (Figure 1): epidermis area on the adaxial and abaxial surfaces; mesophyll area; bulliform cell area; vascular bundle area; area of bundle sheath cells; sclerenchyma area; xylem area and phloem area, epidermis thickness (both surfaces), external paraclinal wall perimeter of the bulliform cells and the common epidermis cells (both surfaces). The following characteristics were assessed on the leaf blade surface (Figure 2, A-B) on both surfaces: trichome density, stomata density and length. The area data were transformed in \% compared to the total area and the count and linear measurements were taken from 10 fields per replication.

The data were submitted to analysis of variance and to the Tukey test at 5\% probability. 


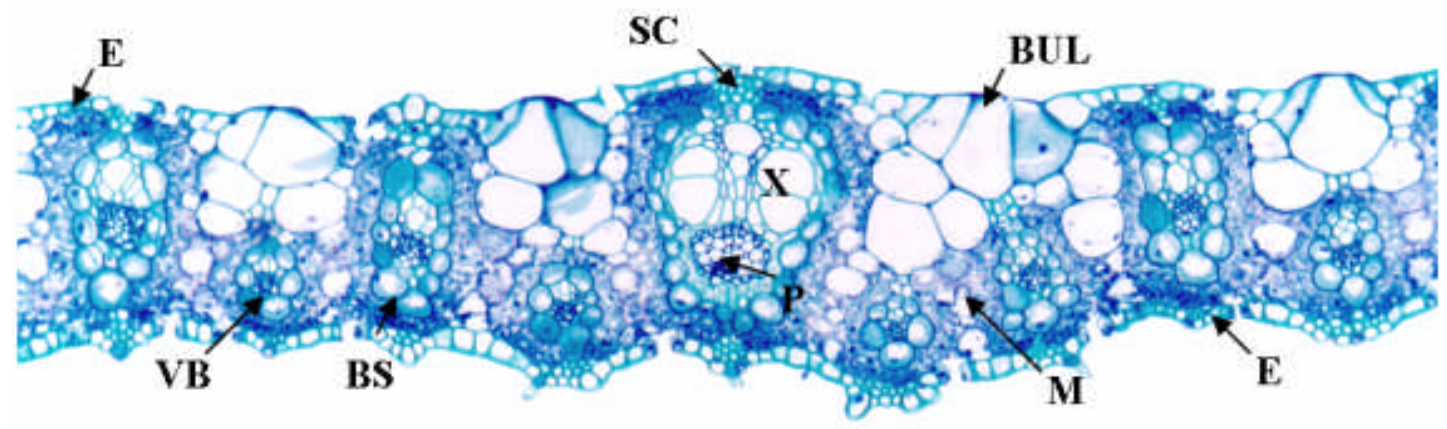

\section{$100 \mu \mathrm{m}$}

Figure 1 - Cross section of sugar cane leaf blade, RB855113 cultivar.Vascular bundles (VB); bundle sheath cells (BS); schlerenchyma (SC); epidermis (E); bulliform cells (BUL); xylem (X), phloem (P) and mesophyll (M).

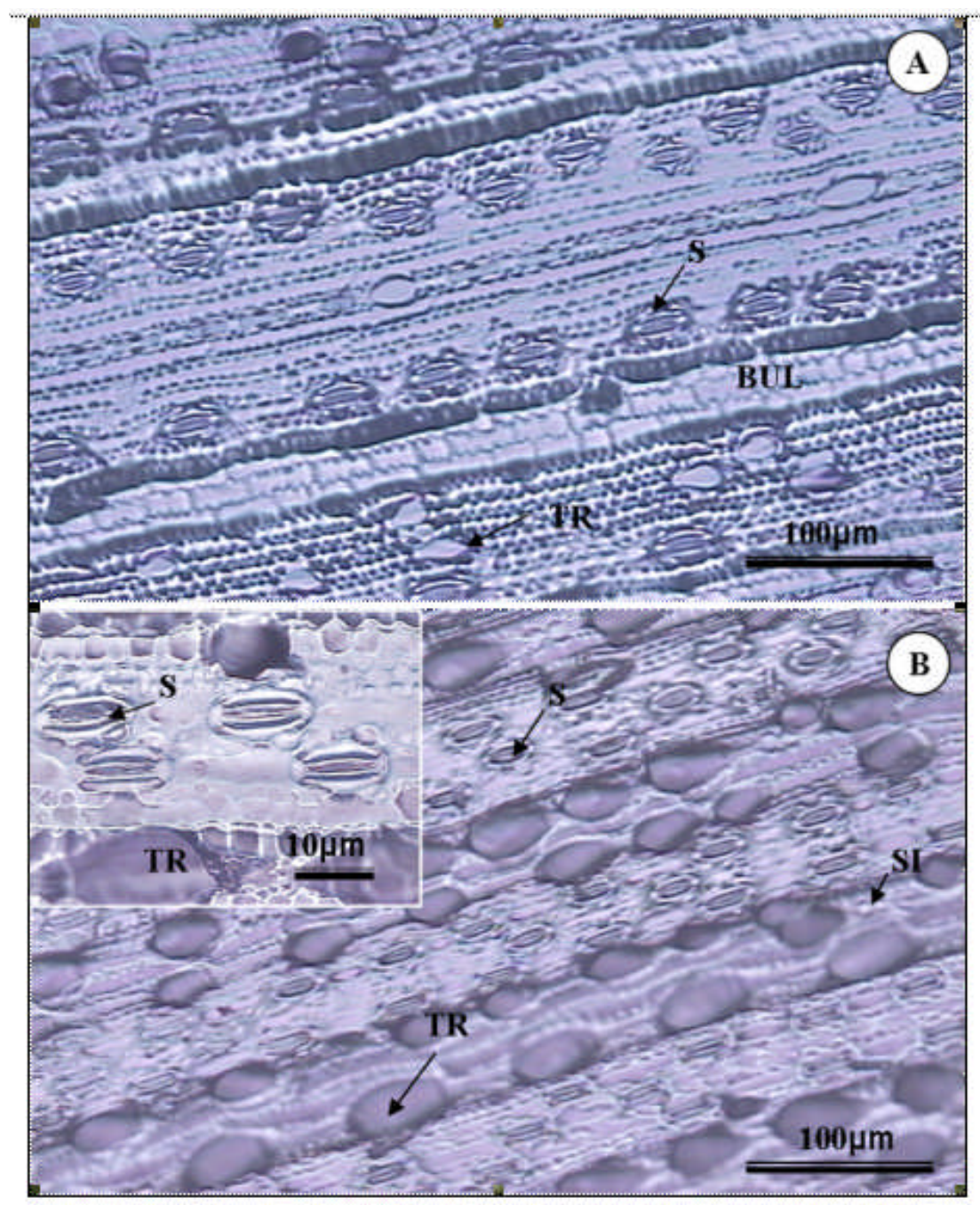

Figure 2 - Paradermic impression of sugar cane leaf blade, RB85511; (A) adaxial surface; (B) abaxial surface. TR: Trichomes; S: stomata; BUL: bulliform cells; SI Silica cells. 
The characteristics considered most relevant to herbicide penetration on the axial and abaxial surfaces were selected, such as trichome density, stomata density, stomata length, epidermis thickness, perimeter of the external paraclinal wall of the bulliform cells, and thickness of the external paraclinal wall of the bulliform cells and common epidermis cells (both surfaces). These data were submitted to statistical analysis using the multivariate analysis of the canonic variables method to cluster the treatments according to their degree of similarity.

\section{RESULTS AND DISCUSSION}

\section{Univariate analysis}

The main cells and tissues present in the sugarcane leaf blade in cross section and paradermic view are presented in Figures 1 and 2 (A and B). The three tissues/cells that occurred in greatest proportion, in decreasing order, in the cross section of the leaf blade of the RB855113, SP80-1842, SP80-1816, RB867515 cultivars and clone RB957689 were the mesophyll, followed by the bulliform cells and the bundle sheath cells of the vascular bundles. The RB855113 cultivar presented the greatest proportion of bulliform cells, followed by mesophyll and the bundle sheath of the vascular bundle (Table 1, Figure 1). RB855113 presented $30.20 \%$ bulliform cells in the cross section of the leaf blade, differing from the others RB867515 (25.15\%), SP801816 (25.15\%), SP80-1842 (24.15\%) and clone RB957689 (24.55\%) (Table 1).The bulliform cells were layers of different widths on the leaf surface (Esau, 1965).

A smaller proportion of bundle sheath cells (13.78\%) was detected in B855113, but it did not differ from RB867515 (15.6 6\%); however, these cultivars differed from clone RB957689 $(17.11 \%)$ and from SP80-1816 (16.60\%) and SP80-1842 (16.97\%) for this characteristic (Table 1).

Cultivars RB957689 and SP80-1842 presented a lower proportion of phloem compared to the other cultivars, respectively, $2.67 \%$ and $2.59 \%$, but did not differ from RB855113 and SP80-1816 which presented an intermediate proportion, with $2.76 \%$ and $2.97 \%$ phloem, but different from clone RB957689 (3.34\%) (Table1). A higher proportion of phloem in a cultivar may be related to the ease of systemic herbicide transportation (Procópio et al., 2003). However, in this case, no relationship was observed between phloem proportion and sensitivity to herbicide mixture.

Stomata density on the adaxial surface of the sugar cane leaves differed among the cultivars. Higher values were observed in RB855113 and clone RB957689 (85.60 and 83.60 stomata $\mathrm{mm}^{-2}$, res pectively), and a lower value in RB867515 (71.20 stomata $\left.\mathrm{mm}^{2}\right)$ (Table 2). RB855113 also presented greater stomata density (163.40 stomata $\mathrm{mm}^{-2}$ ) on the abaxial surface, differing from the other cultivars and clones as sessed: SP80-1842 (140.80 stomata $\left.\mathrm{mm}^{-2}\right)$, SP801816 (144.60 stomata $\mathrm{mm}^{-2}$ ), RB867515 (144.00 stomata $\mathrm{mm}^{-2}$ ) and RB957689

Table 1 - Tissue proportion in relation to total leaf blade area: Vascular bundles (VB); bundle sheath cells (BS); schlerenchyma (SC); adaxial surface epidermis (EDA) abaxial surface epidermis (EBA); bulliform cells (BUL); xylem $(\mathrm{X})$, phloem $(\mathrm{P})$ and mesophyll $(\mathrm{M})$ in five sugarcane genotypes

\begin{tabular}{|l|c|c|c|c|c|c|c|c|c|c|}
\hline \multirow{2}{*}{ Genotype } & VB & BFV & SC & EAD & EAB & BUL & X & P & M \\
\cline { 2 - 12 } & \multicolumn{9}{|c|}{ (\% of tissues in relation to total area) } \\
\hline RB855113 & $10.50 \mathrm{a}$ & $13.78 \mathrm{~b}$ & $3.30 \mathrm{a}$ & $2.99 \mathrm{a}$ & $5.84 \mathrm{a}$ & $30.20 \mathrm{a}$ & $3.03 \mathrm{a}$ & $2.76 \mathrm{ab}$ & $27.55 \mathrm{a}$ \\
\hline RB867515 & $11.22 \mathrm{a}$ & $15.66 \mathrm{ab}$ & $3.34 \mathrm{a}$ & $3.86 \mathrm{a}$ & $5.83 \mathrm{a}$ & $25.15 \mathrm{~b}$ & $3.22 \mathrm{a}$ & $3.34 \mathrm{a}$ & $28.15 \mathrm{a}$ \\
\hline RB957689 & $10.46 \mathrm{a}$ & $17.11 \mathrm{a}$ & $3.22 \mathrm{a}$ & $3.77 \mathrm{a}$ & $6.05 \mathrm{a}$ & $24.55 \mathrm{~b}$ & $2.82 \mathrm{a}$ & $2.67 \mathrm{~b}$ & $29.35 \mathrm{a}$ \\
\hline SP80-1816 & $11.67 \mathrm{a}$ & $16.60 \mathrm{a}$ & $2.73 \mathrm{a}$ & $3.46 \mathrm{a}$ & $6.10 \mathrm{a}$ & $25.10 \mathrm{~b}$ & $3.01 \mathrm{a}$ & $2.97 \mathrm{ab}$ & $28.29 \mathrm{a}$ \\
\hline SP80-1842 & $11.31 \mathrm{a}$ & $16.97 \mathrm{a}$ & $3.58 \mathrm{a}$ & $3.59 \mathrm{a}$ & $5.80 \mathrm{a}$ & $24.37 \mathrm{~b}$ & $3.16 \mathrm{a}$ & $2.59 \mathrm{~b}$ & $28.61 \mathrm{a}$ \\
\hline CV\% & 6.17 & 7.14 & 18.00 & 13.71 & 11.02 & 2.58 & 11.03 & 10.69 & 4.31 \\
\hline
\end{tabular}

Means followed by the same letter in the same column did not differ by the Tukey test $(\mathrm{P}<0.05)$. 
(139.8 stomata $\mathrm{mm}^{-2}$ ) (Table 2). It should be kept in mind that in agricultural herbicide spraying, it is very difficult for the drops to reach the abaxial surface; consequently, the importance of absorption through the abaxial stomata is thought to be minimal. Another factor that may reduce the importance of herbicide absorption through the stomata may be that they are closed at various times of day and also during the night. However, Taylor et al. (1980) stated that the stomata were the main paths of bentazon penetration in Chenopodium album.

Regarding stomata size, RB 855113 presented longer length, on both surfaces, with a mean value of $23.41 \mu \mathrm{m}$ on the adaxial surface and $26.05 \mu \mathrm{m}$ on the abaxial surface (Table 3). The stomata cells are covered with a cuticle that extends to the sub-stomata chambers, and can be completely covered by wax (Esau, 1982).RB855113 presented greatest stomata density and greatest length; these characteristics may be important factors in the greater sensitivity of this cultivar to the herbicide mixture.

Regarding the presence of trichomes in the sugar cane leaf limbo, RB855113 presented greatest density on the adaxial and abaxial surfaces $\left(31.28\right.$ and 121.04 trichomes $\mathrm{mm}^{-2}$, respectively, differing from the other cultivars. Lower trichome density was observed in SP801816 and SP80-1842 on the adaxial surface. However, in SP80-1816, RB867515 and in clone RB957689, lower trichome density was observed on the abaxial surface (Table 2). Sargent and Blackman (1962) reported that the cuticle was more permeable on the base of the trichomes; thus substance penetration could be facilitated in this region. However, Hess \& Falk (1990) reported that the trichomes formed a barrier to herbicide penetration. These authors noted that herbicide, adhered to the trichomes without reaching the epidermis. According to Motomura et al. (2000), silica deposition is common on grass trichome walls, giving them greater resistance to herbicide transport.

When the epidermis thickness of the five genotypes was compared, it was observed that RB855113 presented the least thick epidermis $(13.09 \mu \mathrm{m})$ on the adaxial surface but did not differ from SP80-1842 (14.36 $\mu \mathrm{m})$ and both were different from the other cultivars. No statistical difference was observed among the cultivars on the abaxial surface (Table 3). Most of the herbicide applied by spraying is intercepted preferably by the adaxial leaf surface, and is not usually deposited on the abaxial surface; thus, the adaxial surface is more important in herbicide interception and penetration (Hess \& Falk, 1990).

Analysis of the perimeter of the external paraclinal wall of the bulliform cells showed that SP80-1842 presented greatest perimeter $(98.64 \mu \mathrm{m})$, this did not differ significantly from RB855113 (98.6464 $\mu \mathrm{m})$ but differed from RB867515 and clone RB957689, which had less bulliform cell perimeter, with mean values of 86.98 and $75.43 \mu \mathrm{m}$, respectively.

Table 2 - Mean values of stomata density on the adaxial and abaxial surfaces (DAD and DAB), and trichome density on the adaxial and abaxial surfaces (TAD and TAB) in sugar cane genotypes

\begin{tabular}{|l|c|c|c|c|}
\hline \multirow{2}{*}{ Genotype } & \multicolumn{2}{|c|}{ Stomata $\mathrm{mm}^{-2}$} & \multicolumn{2}{c|}{ Trichomes $\mathrm{mm}^{-2}$} \\
\cline { 2 - 5 } & DAD & DAB & TAD & TAB \\
\hline RB855113 & $85.60 \mathrm{a}$ & $163.40 \mathrm{a}$ & $31.25 \mathrm{a}$ & $121.04 \mathrm{a}$ \\
\hline RB867515 & $71.20 \mathrm{~b}$ & $144.00 \mathrm{~b}$ & $25.58 \mathrm{~b}$ & $88.44 \mathrm{bc}$ \\
\hline RB957689 & $83.60 \mathrm{a}$ & $139.80 \mathrm{~b}$ & $26.30 \mathrm{~b}$ & $85.56 \mathrm{bc}$ \\
\hline SP80-1816 & $77.00 \mathrm{ab}$ & $144.60 \mathrm{~b}$ & $19.18 \mathrm{c}$ & $98.12 \mathrm{~b}$ \\
\hline SP80-1842 & $77.60 \mathrm{ab}$ & $140.80 \mathrm{~b}$ & $16.84 \mathrm{c}$ & $82.81 \mathrm{c}$ \\
\hline CV(\%) & 7.12 & 3.69 & 10.85 & 7.53 \\
\hline
\end{tabular}

Means followed by same letter in the same column did not differ by the Tukey test $(\mathrm{P}<0.05)$.

Table 3 - Mean stomatal length value on the adaxial and abaxial surfaces (COAD and $\mathrm{COAB}$ ), epidermis thickness on the adaxial and abaxial surfaces (EEAD and EEAB) and external paraclinal wall perimeter of the bulliform cells (PEB) in sugar cane genotypes

\begin{tabular}{|l|c|c|c|c|c|}
\hline \multirow{2}{*}{ Genotype } & COAD & COAB & EEAD & EEAB & PEB \\
\cline { 2 - 6 } & \multicolumn{5}{|c|}{$(\mu \mathrm{m})$} \\
\hline RB855113 & $23.42 \mathrm{a}$ & $26.06 \mathrm{a}$ & $13.09 \mathrm{~b}$ & $12.22 \mathrm{a}$ & $98.64 \mathrm{ab}$ \\
\hline RB867515 & $21.10 \mathrm{~b}$ & $23.49 \mathrm{~b}$ & $15.54 \mathrm{a}$ & $12.42 \mathrm{a}$ & $81.95 \mathrm{c}$ \\
\hline RB957689 & $21.27 \mathrm{~b}$ & $23.86 \mathrm{~b}$ & $15.23 \mathrm{a}$ & $12.50 \mathrm{a}$ & $75.43 \mathrm{c}$ \\
\hline SP80-1816 & $19.76 \mathrm{~b}$ & $22.67 \mathrm{bc}$ & $15.44 \mathrm{a}$ & $12.45 \mathrm{a}$ & $108.29 \mathrm{a}$ \\
\hline SP80-1842 & $19.58 \mathrm{~b}$ & $21.52 \mathrm{c}$ & $14.62 \mathrm{ab}$ & $11.80 \mathrm{a}$ & $89.99 \mathrm{bc}$ \\
\hline CV(\%) & 4.52 & 4.16 & 5.39 & 7.39 & 19.74 \\
\hline
\end{tabular}

Means followed by same letter in the same column did not differ by the Tukey test $(\mathrm{P}<0.05)$. 
No difference was observed among the cultivars in external bulliform cell paraclinal wall thickness (Table 4). RB867515 presented greatest external paraclinal wall thickness in the epidermis cells on the adaxial surface $(4.71 \mu \mathrm{m})$, differing from clone RB957689 and cultivar SP80-1842 (4.06 and $3.97 \mu \mathrm{m}$, respectively). However, they did not differ from RB855113 and SP80-1816 (4.42 and $4.14 \mu \mathrm{m})$. RB867515 also presented greater external paraclinal wall thickness of the epidermis cells on the abaxial surface $(4.29 \mathrm{~m})$, differing from clone RB957689 (3.5 $\mu \mathrm{m})$, SP80$1816(3.88 \mu \mathrm{m})$ and SP80-1842 (3.75 $\mu \mathrm{m})$, but not from RB855113 (3.85 $\mu \mathrm{m})$ (Table 4).
Table 4 - Mean values of the external paraclinal wall thickness of the bulliform cells (PBL), on the epidermis cells on the adaxial surface (PAD) and on the abaxial surface (PAB) of the sugar cane genotypes. Means followed by the same lowercase letter in a column did not differ statistically by the Tukey test $(\mathrm{P}<0.05)$

\begin{tabular}{|l|l|l|c|c|}
\hline \multirow{2}{*}{ Genotype } & EBL & EAD & EAB & CV (\%) \\
\cline { 2 - 5 } & \multicolumn{4}{|c|}{$(\mu \mathrm{m})$} \\
\hline RB855113 & $2.38 \mathrm{Ab}$ & $4.24 \mathrm{abA}$ & $3.85 \mathrm{abA}$ & 6.91 \\
\hline RB867515 & $2.44 \mathrm{aB}$ & $4.71 \mathrm{aA}$ & $4.29 \mathrm{aA}$ & 6.78 \\
\hline RB957689 & $2.66 \mathrm{aC}$ & $4.06 \mathrm{bA}$ & $3.50 \mathrm{bB}$ & 5.86 \\
\hline SP80-1816 & $2.78 \mathrm{aB}$ & $4.14 \mathrm{abA}$ & $3.88 \mathrm{abA}$ & 5.00 \\
\hline SP80-1842 & $2.67 \mathrm{aB}$ & $3.97 \mathrm{bA}$ & $3.75 \mathrm{abA}$ & 6.50 \\
\hline CV(\%) & 8.18 & 7.39 & 7.57 & \\
\hline
\end{tabular}

Means followed by the same upper case letter in the same column did not differ statistically by the Tukey test $(\mathrm{P}<0.05)$.

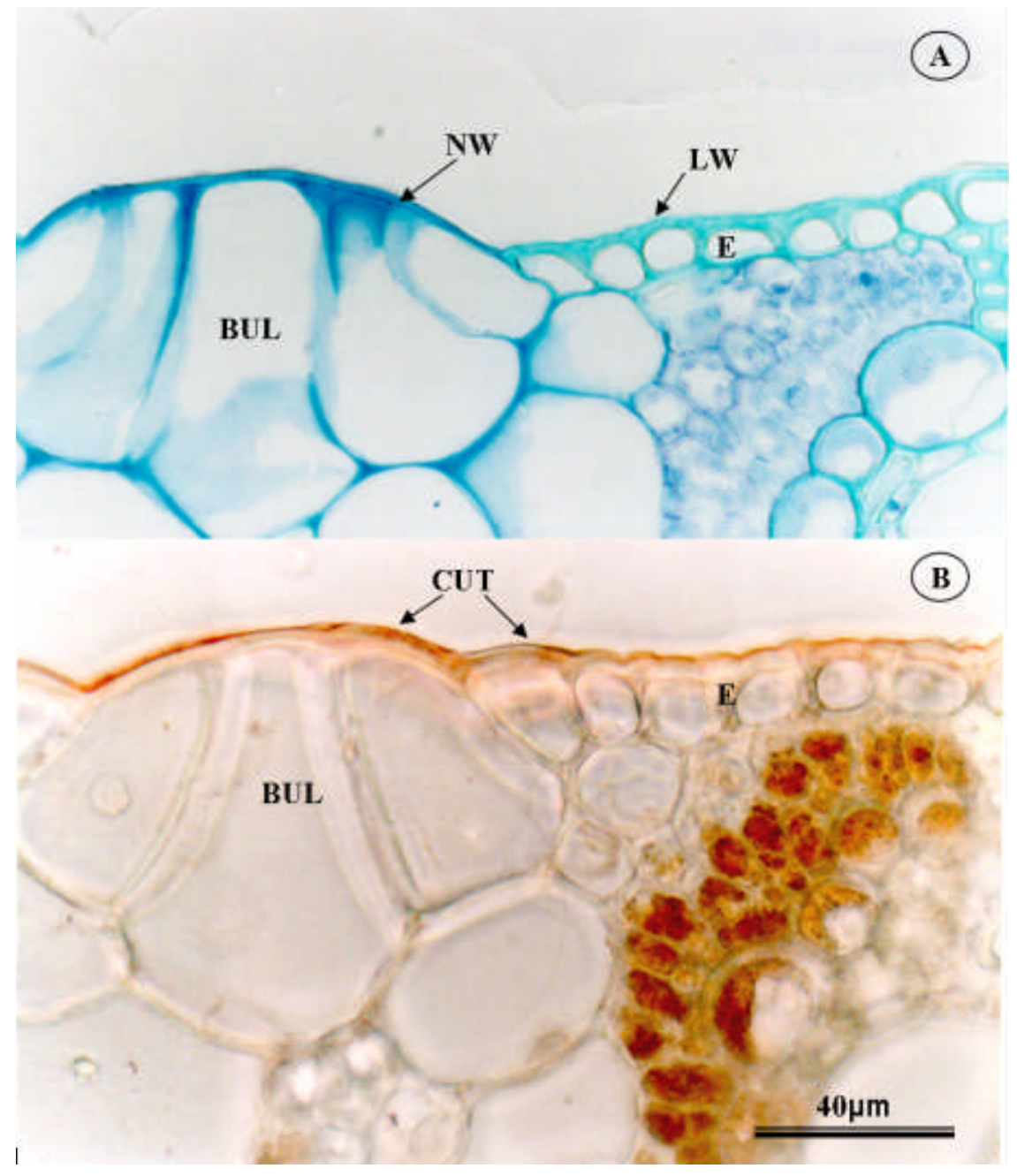

Figure 3 -Detail of the cross section of sugarcane leafblade, RB855113, SP80 1842, SP80 1816, RB867515; (A) stained with toluidina blue; (B) stained with scarlet red sudan. E: epidermis, and cell; BUL: bulliform cells; LW: lignified wall; NW non-lignified wall; CUT: cuticle. 
When thicknesses of the external paraclinal wall of the bulliform cells and common epidermis cells were compared on both surfaces in all the cultivars, the wall was found to be thinner over the former (Table 4). It was also observed that the external paraclinal wall of the common epidermis cells presented a greenish blue coloring on the adaxial and abaxial surfaces, indicating the presence of lignification and intense blue coloring over the bulliform cells that indicated absence of lignification (Figure 3A). According to O'Brien et al. (1964), toluidin blue stain at $\mathrm{pH} 4$ gives differentiated coloring depending on the chemical composition of the tissue analyzed; the lignified wall presents a greenish blue coloring due to lignin, a phenol compound present in the wall. The wall without this compound presented an intense blue coloring. The material stained with scarlet red sudan (Figure 3B) revealed the presence of an orangelike color thin cuticle layer over the external paraclinal wall of all the epidermis cells.

As the external paraclinal wall of the bulliform cells presented cuticle deposition similar to the other epidermis cells (Figure 3B), lignin absence in these walls (Figure 3A), combined with reduced thickness, may make this region a preferential path for herbicide penetration.

\section{Multivariate analysis}

The canonic variable technique consists of the transforming the original variables into standardized and non-correlated variables, with the conglomeration process based on the Mahalanobis distance (Mahalanobis, 1956, quoted by Cruz, 1990). The new set of variables, when ranked, retains maximum information on total variation. These variables will better explain the variability shown.

A set of 12 variables was selected for multivariate analysis considered most related to herbicide penetration (trichome density on both surfaces, stomata density and length on both surfaces, epidermis thickness on both surfaces, external paraclinal wall of the bulliform cells, perimeter of the bulliform cells, external paraclinal wall of the bulliform cells, thickness of the common epidermis cells and the bulliform cells on both surfaces). Hess et al. (1990) and Procópio et al. (2003) stated that the main anatomic factors that would influence herbicide penetration were the trichomes, stomata, cuticle and wall.

Due to high value of information retained in the CAN1 Canonic variable (78.99\%) (Table 5), this first Canonic variable can be considered sufficient to explain the contribution of the original variables analyzed, for the five cultivars in five blocks. For the second Canonic variable (CAN2), the analysis in Table 5 shows that $12.49 \%$ of the information was retained. Thus, the first two variables explained $91.48 \%$ of the total variation in the original data. According to Regazzi (1998), when the first variables explain more than $80 \%$ of the total variation, divergence study is viable by the distance among cultivars on the dispersion graphs, whose coordinates are scores related to the first canonic variables.

Cluster analys is aims to group the treatments in various clusters by applying some ranking criteria so that there is homogeneity within the group and heterogeneity among the groups. Alternatively, cluster analys is techniques aim to divide an original group of observations into various clusters, according to some criteria of similarity or dissimilarity among the treatments (Cruz \& Regazzi, 1997). The Tocher optimization method distributed the five cultivars studied into groups, the first formed by RB867515, RB957689, SP80-1842, SP80-1816, and RB867515 and the second by the RB855113 cultivar.

The 12 variables analyzed were efficient in distinguishing two groups of cultivars. The SP80-1842, SP80-1816 cultivars and clone RB957689, presenting medium sensitivity to the sodium trifloxysulfuron + ametryn to herbicide mixture, were placed with RB867515, tolerant to herbicide mixture.RB855113 cultivar, sensitive to the mixture, was isolated as a separate group (Figure 5).

Joint analysis of the data showed that RB855113, sensitive to the herbicide mixture, differed from the other cultivars in various characteristics with a greater proportion of bulliform cells, greater stomata density on both surfaces, stomata with greater length on both surfaces, greater trichome density on both surfaces, and thinner epidermis on the adaxial 
Table 5 - Correlations among the 12 original variables regarding the anatomy of the cross section of sugar cane leaf blade, and the two Canonic variables (CAN1 and CAN2). Percentage of information retained and accumulated in CAN1 and CAN2, and ranking of the variables for their discriminatory power

\begin{tabular}{|c|c|c|c|c|}
\hline Variable & CAN1 & Order & CAN2 & Order \\
\hline Stomata density of the adaxial surface $\left(\mathrm{mm}^{-2}\right)$ & 0.05 & 10 & 0.20 & 5 \\
\hline Stomata density of the abaxial surface $\left(\mathrm{mm}^{-2}\right)$ & 0.19 & 6 & -0.24 & 10 \\
\hline Trichome density of the adaxial surface $\left(\mathrm{mm}^{-2}\right)$ & 0.34 & 3 & 0.22 & 4 \\
\hline Trichome density of the abaxial surface $\left(\mathrm{mm}^{-2}\right)$ & 0.06 & 9 & -0.01 & 7 \\
\hline Stomata length of the adaxial surface $(\mu \mathrm{m})$ & 0.29 & 5 & 0.28 & 3 \\
\hline Stomata length of the abaxial surfaces $(\mu \mathrm{m})$ & 0.17 & 7 & -0.12 & 8 \\
\hline Epidermis thickness of the adaxial surface $(\mu \mathrm{m})$ & -0.33 & 12 & -0.33 & 12 \\
\hline Epidermis thickness of the abaxial surface $(\mu \mathrm{m})$ & 0.34 & 4 & 0.10 & 6 \\
\hline Perimeter of the external paraclinal wall of the Bulliform cells $(\mu \mathrm{m})$ & 0.54 & 1 & -0.19 & 9 \\
\hline Thickness of the external paraclinal wall of the bulliform cells & -0.23 & 11 & -0.25 & 11 \\
\hline $\begin{array}{l}\text { Thickness of the external paraclinal wall of the bulliform cells and common } \\
\text { epidermis cell adaxial surfaces }(\mu \mathrm{m})\end{array}$ & 0.39 & 2 & 0.60 & 1 \\
\hline $\begin{array}{l}\text { Thickness of the external paraclinal wall of the bulliform cells and common } \\
\text { epidermis cell abaxial surfaces }(\mu \mathrm{m})\end{array}$ & 0.10 & 8 & 0.42 & 2 \\
\hline Retained information (\%) & 78.99 & & 91.48 & \\
\hline Accumulated information $(\%)$ & 78.99 & & 12.49 & \\
\hline
\end{tabular}

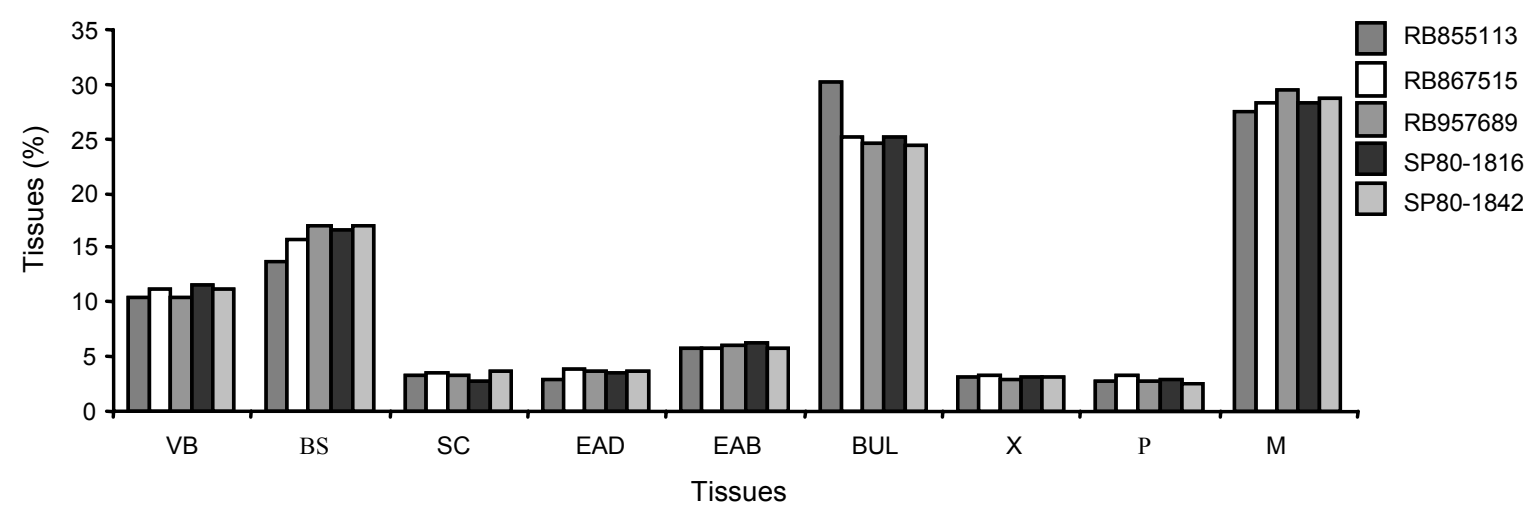

Figure 4 - Proportion of tissues (\%) in relation to total leaf blade area: Vascular bundles (VB); bundle sheath cells (BS); schlerenchyma (SC); adaxial surface epidermis (EDA) abaxial surface epidermis (EBA); bulliform cells (BUL); xylem $(\mathrm{X})$, phloem $(\mathrm{P})$ and mesophyll $(\mathrm{M})$ in five sugar cane genotypes.

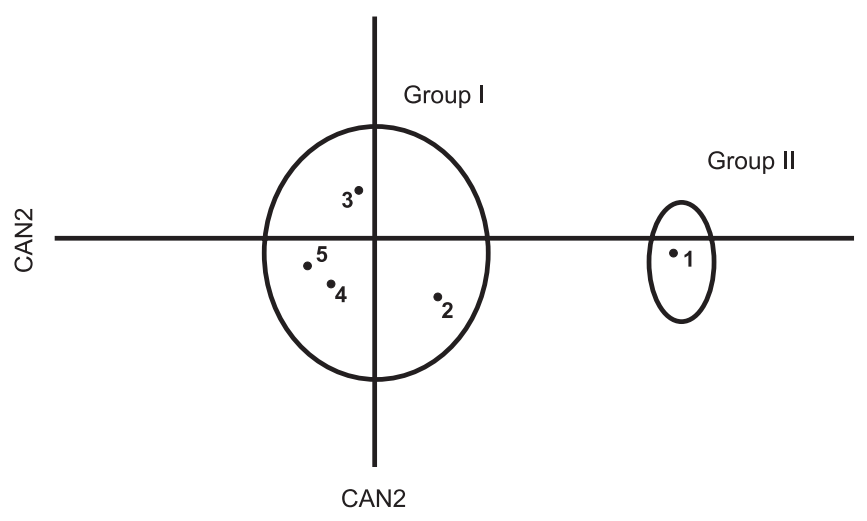

Figure 5 - Graphic dispersion of the five sugar cane genotypes (1-RB855113; 2- RB867515; 3- SP957689; 4- SP80-1816; 5- SP801842), using the two first Canonic variables (CAN1 and CAN2) for the set of 12 variables (trichome density on both surfaces, stomata density and length on both surfaces, epidermis thickness on the adaxial and abaxial surfaces, external paraclinal wall of the bulliform cells, external paraclinal wall of the common epidermis cells and bulliform cells on both surfaces). 
surface than the other cultivars. SP80-1816 and RB855113 presented greater perimeter of the external paraclinal wall of the bulliform cells. As already discussed, such characteristics can explain their greater sensitivity to the sodium trifloxysulfuron + ametryn mixture.

Multivariate analysis of the data related to the variables considered most relevant to explain herbicide penetration distinguished the sensitive RB855113 cultivar from the other materials, indicating that the set of 12 variables was efficient to form this clustering, but it did not separate the cultivar groups with medium sensitivity from the cultivars tolerant to the mixture.

\section{LITERATURE CITED}

ARTSCHWAGER, H. S. A. Anatomy of the vegetative organs of sugarcane. J. Agric., v. 30, p. 197-221, 1925.

COMISSÃO DE FERTILIDADE DO SOLO DO ESTADO DE MINAS GERAIS - CFSEMG. Recomendações para o uso de corretivos e fertilizantes em Minas Gerais - 5a aproximação. Viçosa, MG: Universidade Federal de Viçosa, 1999. 359 p.

CRUZ, C. D. Aplicações de algumas técnicas multivariadas no melhoramento de plantas. Piracicaba: Escola Superior Luiz de Queiroz, 1990. 188 p.

CRUZ, C. D.; REGAZZI, A. J. Modelos biométricos aplicados ao melhoramento genético. Viçosa, MG: Universidade Federal de Viçosa, 1997. 390 p.

ESAU, K. Anatomia de las plantas con semilla. Buenos Aires: Editorial Hemisferio Sur. 1982. 512 p.

FERREIRA, E. A. et al. Estudos anatômicos de folhas de plantas daninhas. I - Nicandra physaloides, Solanum viarum, Solanum americanum e Raphanus raphanistrum. Planta Daninha, n. 2, p. 159-167, 2002.

FERREIRA, E. A. et al. Sensibilidade de cultivares de cana-de-açúcar à mistura trifloxysulfuron-sodium + ametryn. Planta Daninha, v. 23, n. 1, p. 93-99, 2005.

HEREDIA, A. La cutícula vegetal: estructura y funciones. Ecologia, v. 12, p. 293-305, 1998.
HESS, F. D. Absorption. In: HERBICIDE action course. West Laffayete: Purdue University, 1995. 785 p.

HESS, F. D.; FALK, R. H. Herbicide deposition on leaf surfaces. Weed Sci., v. 38, p. 280-28 8, 1990.

HULL, H. M. Leaf structure as related to absorption of pesticides and other compounds. Residue Rev., v. 38, p. $1-155,1970$.

JOHANSEN, D. A. Plant microtechnique. New York: McGraw-Hill Book, 1940. 523 p.

MEYER, B. et al. Introdução à fisiologia vegetal. 2.ed. Lisboa: 1973. 710 p.

PROCÓPIO, S. O. et al. Manejo de plantas daninhas na cultura da cana-de-açúcar. Viçosa, MG: Universidade Federal de Viçosa, 2003. 150 p.

SILVA, A. A.; FERREIRA, F. A.; FERREIRA, L. R. Controle de plantas daninhas. Brasília, DF: ABEAS, 2003. $260 \mathrm{p}$.

PROCÓPIO, S. O. et al. Anatomia foliar de plantas daninhas do Brasil. Viçosa-MG: Universidade Federal de Viçosa, 2003. 118 p.

RODELLA. R. A.; PIRES, A. I.; MAIMONI-RODELLA, R. C. S. Anatomia comparativa foliar e caulinar de duas espécies daninhas de Merremia (Convolvulaceae).

Científica, v. 21, p. 345-353, 1983.

SANTOS, I. C. et al. Características anatômicas de duas espécies de trapoeraba e a eficiência do glyphosate. Planta Daninha, v. 20, p. 1-8, 2001.

SARGENT, J. A.; BLACKMAN, G. E. Studies on foliar penetration. I. Factors controlling the entry of 2,4dicloroacetic acid. J. Exp. Bot., v. 13, p. 384-368, 1962.

TAYLOR, F. E.; COBB, A. H.; DAVIES, L. G. The effects of bentazon on stomatal behavior in Chenopodium album L. New Phytol., v. 63, p. 369-376, 1980.

VAN DILLEWIJN, C. Botany of sugarcane. Waltham: The Chronica Botanica co.: Book Departament. 1957. $371 \mathrm{p}$. 